\section{Effect of Container Color on Substrate Temperatures and Growth of Red Maple and Redbud}

\author{
John W. Markham III ${ }^{1}$, Dale J. Bremer ${ }^{2}$, Cheryl R. Boyer ${ }^{3,5}$, and \\ Kenneth R. Schroeder ${ }^{4}$ \\ Kansas State University, Department of Horticulture, Forestry and Recreation \\ Resources, Manhattan, KS 66506
}

Additional index words. Acer rubrum, Cercis canadensis, heat stress, nursery production, Phaseolus vulgaris, redbud, red maple

\begin{abstract}
Heat stress is problematic to root growth in the production of containerized nursery plants. Container color may moderate effects of solar radiation on substrate temperatures. Studies were conducted near Manhattan, KS, to evaluate effects of container color on growth of roots and shoots in bush beans (Phaseolus vulgaris L.), red maple (Acer rubrum L.), and eastern redbud (Cercis canadensis L.). Four treatments among studies included containers colored flat and gloss white, silver, and black; a green container color treatment was added to the tree studies. Plants were grown in bark-based soil-less substrate and temperatures were measured at $5-\mathrm{cm}$ depths in the south sides and centers. After 4 months, plant variables were measured. Roots were separated into three sections: core, north, and south. In the bean study, substrate temperatures at the south side of the container averaged lowest in flat and gloss white $\left(\approx 36^{\circ} \mathrm{C}\right)$ and greatest in black containers $\left(50.3^{\circ} \mathrm{C}\right)$. Root density at the south side was reduced in beans by $63 \%$ to $71 \%$ in black compared with flat and gloss white. In heat-sensitive maples, substrate temperatures at the south side of containers averaged up to $7.7^{\circ} \mathrm{C}$ greater in black and green than in other treatments. Substrate temperatures in the center averaged 3.5 to $3.8{ }^{\circ} \mathrm{C}$ greater in black than in flat and gloss white, resulting in up to 2.5 times greater root density in flat and gloss white than in black containers. In heat-tolerant redbuds, the effects of container color on whole-plant growth were less evident. Data suggest that heatsensitive plants benefit from being grown in white containers or painting outer surfaces of green and black containers white.
\end{abstract}

Heat stress imposed on roots of containergrown plants is an important problem in the nursery industry. In a number of nurserygrown species, substrate temperatures over $30{ }^{\circ} \mathrm{C}$ may cause root growth to slow considerably (Johnson and Ingram, 1984). Furthermore, in a number of woody species, root growth stops completely at temperatures above $39^{\circ} \mathrm{C}$ (Mathers, 2003). Substrate temperatures inside nursery containers can rise higher than $54{ }^{\circ} \mathrm{C}$ (Ingram et al., 1989; Martin et al., 1989; Mathers, 2000), resulting in crop loss or reduced crop quality. This is especially problematic to some woody species [e.g., Japanese holly (Ilex crenata Thunb. 'Helleri')] because their roots die when exposed to temperatures of $51{ }^{\circ} \mathrm{C}$ for merely $30 \mathrm{~min}$ (Martin et al., 1989).

Received for publication 1 Dec. 2010. Accepted for publication 31 Mar. 2011

Contribution no. 11-077-J from the Kansas Agric. Exp. Station.

We thank Dr. George Milliken for his assistance with statistical analysis.

${ }^{1}$ Graduate Research Assistant.

${ }^{2}$ Associate Professor.

${ }^{3}$ Assistant Professor.

${ }^{4}$ Assistant Professor and Agriculture Agent, University of Wisconsin Extension, Portage County.

${ }^{5}$ To whom reprint requests should be addressed; e-mail crboyer@k-state.edu.
The detrimental effects of heat stress on root growth affect the whole plant and thus also impacts aboveground production. For example, high root-zone temperatures in container-grown nursery plants may cause leaf wilting, chlorosis, and drop; reduce flower numbers and quality; cause abnormal branching; and interfere with normal physiological and biochemical processes (e.g., photosynthesis and respiration, water and nutrient uptake, hormone synthesis, and translocation processes) (Ingram et al., 1989). High root-zone temperatures may also increase the incidence of disease and cause plant injury or death (Ranney and Peet, 1994; Webber and Ross, 1995). Therefore, investigations into the effects of heat stress on root growth in container-grown plants would benefit by including evaluations of whole-plant responses.

It is possible that growing plants in containers made of colors lighter than standard black may improve root growth. Lighter colored containers have greater albedo than dark containers and thus reflect more solar radiation away from the container (i.e., less solar energy absorbed by the container) (Ham et al., 1993). Consequently, lighter colored containers may be a means to mitigate heat stress in nursery production.

Fretz (1971) reported that substrate temperatures were reduced by $5.6^{\circ} \mathrm{C}$ in light- than in dark-colored containers. Whitcomb (1980,
1999, 2003) also found that substrate temperatures were reduced by 3 to $6{ }^{\circ} \mathrm{C}$ when standard black containers were covered with white laminated fabric sleeves (RootSkirts $\AA$; Rootmaker Products Co., Huntsville, AL). Similarly, substrate temperatures were decreased by 1 to $7{ }^{\circ} \mathrm{C}$ in containers made of an insulating black fabric that was coated on the outside with white polyethylene (Whitcomb and Whitcomb, 2006).

Ingram (1981) evaluated the effects of substrate temperature on root growth of flowering dogwood (Cornus florida L.), rhododendron (Rhododendron simsii Planch. 'Formosa'), and japanese pittosporum (Pittosporum tobira Banks) grown in polyethylene bags with a white outer surface and conventional, rigid black containers. In their study, maximum daily temperatures were $6{ }^{\circ} \mathrm{C}$ higher in black containers than in white polyethylene bags. Root growth of plants in white polyethylene bags, with cooler substrate compared with black conventional containers, was three times greater in rhododendron and four times greater in flowering dogwood but unaffected in japanese pittosporum, indicating substantial differences in heat tolerance among species.

Although container-grown species in the nursery industry may vary in their susceptibility to heat stress, all species benefit from developing an extensive root system in propagation and early production (Davidson et al., 2000). If root growth is compromised during production, transplant survival and growth may later be negatively affected in the landscape (Richardson-Calfee et al., 2010). Therefore, investigations into potentially heat-mitigating practices such as the use of lighter colored containers on root growth and distribution may prove beneficial for a number of important nursery crops.

Red maple and eastern redbud are examples of important species in the nursery industry because they are native to the United States, tolerant of a wide range of environmental conditions, and have desirable ornamental characteristics (Dirr, 2009). Wilkins et al. (1995) evaluated several genotypes of red maple for tolerance to high root-zone temperatures and showed that some were relatively sensitive, whereas others demonstrated resistance to heat stress in the root zone. A study by Griffin et al. (2004) revealed that redbud is tolerant of high temperatures and drought.

In this study, we evaluated effects of container color on substrate temperatures, including spatial variability in substrate temperatures. Subsequent effects of container color and substrate temperature on root distribution and shoot development were also evaluated in containergrown maples and redbuds.

\section{Materials and Methods}

Bean study. Several container colors were evaluated first in an experiment with bush beans late in the summer of 2004 to quickly determine appropriate color selections for the woody plant experiments, which were conducted the next summer. Bean plants were grown in soil-less potting substrate (Metro-Mix 
366p; Sun-Gro, British Columbia, Canada) in containers (Classic 1000; Nursery Supplies, Fairless Hills, PA) with 25-cm top and $21-\mathrm{cm}$ bottom diameter, respectively, $23 \mathrm{~cm}$ height, and $8.69 \mathrm{~L}$ volume. Four treatments included container colors of flat white, gloss white, silver, and black as the control. All containers were initially black, but four each were painted flat white, gloss white (ColorPlace Fast Dry Spray Paint, Bentonville, AR), and silver (Rust-oleum Bright Coat Metallic Finish, Vernon Hills, IL). This study as well as the two woody studies were conducted in Manhattan, KS

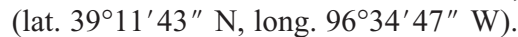

Two soil temperature probes were inserted to a depth of $5 \mathrm{~cm}$ in each container with one probe at the container-substrate interface on the south side and one in the center. Soil temperature probes were constructed by longitudinally centering copper-constantan thermocouple junctions (Type T, 24 AWG, TT-T-24; Omega, Stamford, CT) in segments of copper tubing $(7.5 \mathrm{~cm}$ in length $\times 6.4 \mathrm{~mm}$ diameter $)$ and filling the tubes with thermally conductive epoxy (Omegabond 101; Omega Engineering, Stamford, CT). Substrate temperatures were recorded hourly with a data logger and multiplexer (CR10x, AM16/32; Campbell Scientific, Logan, UT).

After $40 \mathrm{~d}$ in the field (21 Aug. to 30 Sept. 2004), fruit and shoot biomass were harvested. A $15-\mathrm{cm}$ diameter galvanized stove pipe was used to extract the core of the roots by slicing substrate in each container from top to bottom. To determine differences in root growth between south (sun-facing side during midday) and north sides, a sheet metal "slicer" was fabricated to separate the remaining soil-less substrate along the inside perimeter of the containers into north and south halves. Roots in all three sections, (i.e., core, north, and south halves) were rinsed carefully, placed in paper bags, dried at $66{ }^{\circ} \mathrm{C}$ for $48 \mathrm{~h}$ in a forced-air convection oven, and weighed; aboveground biomass was dried and weighed in the same manner.

The experimental design was a repeated measures type of design with containers representing large size of experimental unit (color) and position within the container representing the repeated measured factor (core, north, and south). The large size of experimental units included four repetitions of each color for a total of 16 containers that were arranged in a completely randomized design. Position within a container could not be randomized resulting in a repeated-measures design. Data were analyzed with the mixed procedures of SAS (SAS Institute, Cary, NC). Differences between means were separated by Fisher's protected least significant difference $(P=0.05)$. Tests for interactions between container color and position within containers were conducted with two-way analysis of variance $(P=0.05)$.

Container-grown tree study. One hundred, bare-root, 1-year-old seedlings (Lawyer Nursery Co., Plains, MT) of redbud and red maple were transplanted into plastic containers in mid-May 2005 (Classic 600, Nursery Supplies; $7.57 \mathrm{~L}, 20 \mathrm{~cm}$ diameter) using soilless substrate (MetroMix 702; Sun-Gro) and controlled-release fertilizer $\left(8.3 \mathrm{~kg} / \mathrm{m}^{3} 19 \mathrm{~N}-\right.$ 2.6P-9.9K, Osmocote 19-6-12; Scotts-Sierra, Marysville, $\mathrm{OH})$. Containers were then placed in a greenhouse and maintained at $22{ }^{\circ} \mathrm{C}$ (day) and $15^{\circ} \mathrm{C}$ (night) until all trees began to break bud.

Five treatments included container colors of flat white, gloss white, silver, green, and black. Like in the bean study, all containers were initially black but some were spraypainted flat white, gloss white, and silver according to their treatment. Green containers (Classic 600; Nursery Supplies) were used as manufactured. Initial measurements were taken of tree height, number of active buds, and stem caliper at $7.5 \mathrm{~cm}$ above the substrate surface.

Container-grown trees were placed on an open, level site in which spots of vegetation surrounding each container ( $0.6 \mathrm{~m}$ diameter $)$ had been killed with glyphosate (Roundup, $1.12 \mathrm{~kg}$ ai/ha; Monsanto, Marysville, $\mathrm{OH}$ ). Containers were arranged in a completely randomized design, spaced 5 feet apart, with cedar mulch under each container to hold the container above the natural soil level and thus confine all root growth inside the container. Containers remained in this configuration from 26 June to 27 Oct. 2005 and were watered to saturation with cool water as needed.

Two soil-temperature probes were inserted to a depth of $5 \mathrm{~cm}$ in five containers of each treatment of maple plants. Like in the bean study, one probe was placed at the south side and the other in the center of each container;

Table 1 . In bush beans, daily maximum substrate temperatures averaged over the duration of the study, among container-color treatments $(n=4){ }^{2}$

\begin{tabular}{|c|c|c|c|}
\hline \multirow[b]{2}{*}{ Container color } & South & Center & Difference (south-center) \\
\hline & \multicolumn{3}{|c|}{ 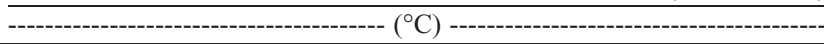 } \\
\hline Flat white & $36.9 C^{y} a^{x}$ & $31.0 \mathrm{Bb}$ & 5.9 \\
\hline Gloss white & $35.6 \mathrm{Ca}$ & $33.1 \mathrm{Ba}$ & - \\
\hline Silver & $41.5 \mathrm{Ba}$ & $32.8 \mathrm{Bb}$ & 8.7 \\
\hline Black & $50.3 \mathrm{Aa}$ & $37.3 \mathrm{Ab}$ & 13 \\
\hline
\end{tabular}

${ }^{z}$ Substrate temperatures were measured at $5 \mathrm{~cm}$ at the south edge and in the center.

${ }^{y}$ Means followed by the same upper-case letter within a column were not significantly different $(P=0.05)$.

${ }^{\mathrm{x}}$ Means followed by the same lower-case letter within a row were not significantly different $(P=0.05)$.

Table 2. In bush beans, average root densities in the north and south sections of black, flat white, gloss white, and silver containers $(n=4)$.

\begin{tabular}{|c|c|c|c|}
\hline \multirow[b]{2}{*}{ Container color } & South & North & Difference (north-south) \\
\hline & \multicolumn{3}{|c|}{ 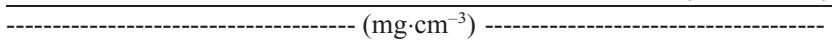 } \\
\hline Flat white & $0.217 \mathrm{~A}^{\mathrm{z}} \mathrm{a}^{\mathrm{y}}$ & $0.247 \mathrm{Aa}$ & - \\
\hline Gloss white & $0.172 \mathrm{ABb}$ & $0.269 \mathrm{Aa}$ & 0.097 \\
\hline Silver & $0.126 \mathrm{Bb}$ & $0.258 \mathrm{Aa}$ & 0.132 \\
\hline Black & $0.063 \mathrm{Cb}$ & $0.214 \mathrm{Aa}$ & 0.151 \\
\hline
\end{tabular}

${ }^{\mathrm{z}}$ Means followed by the same upper-case letter within a column were not significantly different $(P=0.05)$.

${ }^{\mathrm{y}}$ Means followed by the same lower-case letter within a row were not significantly different $(P=0.05)$.

Table 3. In bush beans, average root densities in the cores and in entire containers, and average aboveground biomass among container color treatments $(n=4)$.

\begin{tabular}{|c|c|c|c|c|}
\hline \multirow[b]{3}{*}{ Container color } & \multicolumn{2}{|c|}{ Root density } & \multicolumn{2}{|c|}{ Aboveground biomass } \\
\hline & Container core & Container total & Fruit dry wt & Shoot dry wt \\
\hline & \multicolumn{2}{|c|}{ 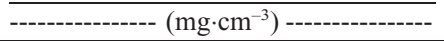 } & \multicolumn{2}{|c|}{ 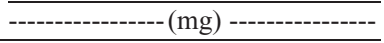 } \\
\hline Flat white & $0.684 \mathrm{AB}^{\mathrm{z}}$ & $0.431 \mathrm{~A}$ & $7.38 \mathrm{~A}$ & $16.1 \mathrm{AB}$ \\
\hline Gloss white & $0.638 \mathrm{~B}$ & $0.394 \mathrm{AB}$ & $9.06 \mathrm{~A}$ & $17.9 \mathrm{AB}$ \\
\hline Silver & $0.756 \mathrm{~A}$ & $0.427 \mathrm{~A}$ & $7.22 \mathrm{~A}$ & $18.6 \mathrm{~A}$ \\
\hline Black & $0.707 \mathrm{AB}$ & $0.380 \mathrm{~B}$ & $7.65 \mathrm{~A}$ & $15.6 \mathrm{~B}$ \\
\hline
\end{tabular}

${ }^{\mathrm{z}}$ Means followed by the same letter within a column were not significantly different $(P=0.05)$. 
Table 4. In red maples, average substrate temperatures at $5 \mathrm{~cm}$ at the south edge and in the center, and differences between the two locations (center-south), among treatments $(\mathrm{n}=5)$.

\begin{tabular}{lllc}
\hline & \multicolumn{1}{c}{ South } & Center & Difference (south-center) \\
\cline { 2 - 4 } Container color & $36.8 \mathrm{~B}^{\mathrm{z}} \mathrm{a}^{\mathrm{y}}$ & $33.3 \mathrm{Bb}$ & 3.5 \\
\hline Flat white & $37.4 \mathrm{Ba}$ & $33.6 \mathrm{Bb}$ & 3.8 \\
Gloss white & $38.1 \mathrm{Ba}$ & $33.6 \mathrm{Bb}$ & 4.5 \\
Silver & $43.0 \mathrm{Aa}$ & $37.6 \mathrm{Ab}$ & 5.4 \\
Green & $44.5 \mathrm{Aa}$ & $37.1 \mathrm{Ab}$ & 7.4 \\
Black & &
\end{tabular}

${ }^{2}$ Means followed by the same upper-case letter within a column were not significantly different $(P=0.05)$

${ }^{y}$ Means followed by the same lower-case letter within a row were not significantly different $(P=0.05)$.
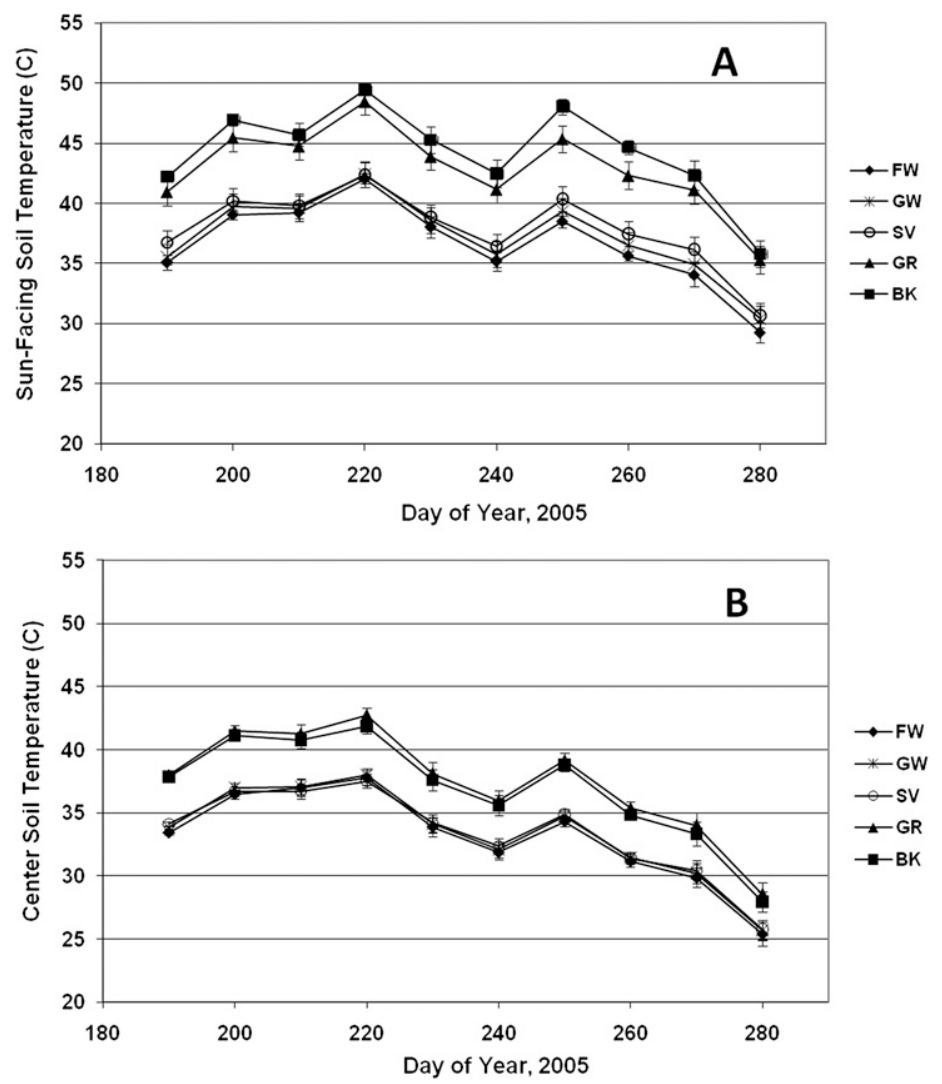

Fig. 1. Daily maximum substrate temperatures at $5 \mathrm{~cm}$ at the south side (A) and center (B) of flat white (FW), gloss white $(\mathrm{GW})$, silver (SV), green (GR), and black (BK) containers in maples. Data are presented as 10-d averages to show seasonal trends. Error bars denote SE and are smaller than symbols in some instances.

and $-0.6{ }^{\circ} \mathrm{C}$, respectively. Redbuds, however, retained their leaves after the frost. During the first week of November, leaves were removed from the redbuds, leaf area was measured, and the samples were then dried at $66^{\circ} \mathrm{C}$ for $48 \mathrm{~h}$ and weighed.

At the end of the study, aboveground measurements of total shoot length, total number of branches, and final stem caliper at $7.5 \mathrm{~cm}$ above the surface were collected for all trees in both species. In addition, the tallest shoot length was measured in maples. Redbuds had branched in a manner rendering it impossible to determine a central "leader" and therefore, the tallest shoot length was not measured. Supplemental measurements on the redbuds included the number of branches below the 7.5-cm caliper standard and the caliper below all branches. This measurement was not needed on the red maples because they developed a strong leader and there were no branches below measurement. A repeated-measures analysis of variance was conducted to evaluate differences in trends across days during the study among color treatments and probe positions.

\section{Results and Discussion}

Bean study. There was significant interaction between container color and probe position and thus, temperature data are presented separately by color and position (Table 1). Daily maximum substrate temperatures at the south (sun-facing side during midday) side of containers averaged over all container colors ranged from 35.6 to $50.3{ }^{\circ} \mathrm{C}$. These temperatures are high enough to impede growth of or even kill roots in a number of species (Fretz, 1971). In flat white, gloss white, and silver containers, substrate temperatures were 14.7 to $8.8^{\circ} \mathrm{C}$ lower than black containers at the south side; cooler substrates in the lighter colored containers were likely caused by their greater albedo. Substrate temperature in silver containers was also higher than in gloss white and flat white containers on the south side, indicating greater potential for damage of roots in silver than in flat and gloss white containers.

Substrate temperatures at the center were 5.9 to $13{ }^{\circ} \mathrm{C}$ cooler than at the south side among treatments with the exception of gloss white containers, which was similar at both locations (Table 1). Black containers exhibited the greatest temperature difference between the south side and the center. Nevertheless, substrate temperatures at the center remained greatest in black containers, whereas center temperatures were similar among flat white, gloss white, and silver containers. Overall, substrate temperatures were greatest in black containers at both the south side and at the center.

Root density in the south side of black containers was $63 \%$ and $71 \%$ less than in gloss and flat white containers, respectively, and $50 \%$ less than in silver containers (Table 2); a similar trend existed in the temperature results (Fig. 1). There was significant interaction between color and position in root density. Root density in flat white, silver, and black containers followed a reverse trend from substrate temperatures (Table 1); root density decreased presumably as a result of increasing substrate temperature among these treatments. The reduction in root biomass in black containers among treatments illustrates the detrimental effects of higher substrate temperatures on root growth and development.

On the north side of containers, there were no differences in root density among treatments (Table 2), which reflects the smaller differences in substrate temperature among treatments away from the south side (Table 1). The differences in root density between north and south sides were $36 \%$ smaller in gloss white and 13\% smaller in silver than in black containers, which indicate the heat-moderating effects of lighter colored containers. Root density of bush beans grown in black containers was $71 \%$ lower in the south side than in the north, which again revealed the effects of hot substrates on root development in the south side. Like with temperature, there were significant interactions between container 
color and position (i.e., root density between north and south).

Root density in the core was similar between black and all other containers although substrate temperatures were highest in the centers of the black containers (Tables 1 and 2). It is possible that the cultivar of Phaseolus vulgaris L. in our study was moderately heattolerant (Omae et al., 2006; Petkova et al., 2007), which may have diminished the effects of temperature on root growth in cores of black containers; temperatures in the center averaged $13{ }^{\circ} \mathrm{C}$ lower than at the south side. However, total root density of bush beans in black containers was lower than in flat white and silver containers (Table 3 ). The negative effects of high temperature on root growth in the south side, which reduced total root density in black containers, illustrates the need to adapt management practices that mitigate heat in containergrown nursery stock.

The effects of high temperature on aboveground growth were less conclusive with the possible exception of shoot dry weight. For example, shoot dry weight was less in black containers than in silver containers, which suggests that higher temperatures in black containers reduced shoot growth (Table 3 ). No differences were observed, however, in fruit dry weight among treatments. As mentioned earlier, it is possible that the bean cultivar used in this study was heat-tolerant, which may have minimized high-temperature effects on shoot growth.

\section{Tree study}

Red maple. Substrate temperatures at the south side of containers, recorded over a 90-d period, fell into two distinct groups among treatments. Repeated-measures analysis of variance of 10-d averages revealed that substrates in black and green containers were consistently warmer than substrates in flat white, gloss white, and silver containers (Fig. 1A). Daily maximum temperatures, when averaged over the entire $90 \mathrm{~d}$, ranged from 4.9 to $7.7^{\circ} \mathrm{C}$ higher in black and green containers than in other containers (Table 4 ); there was a significant interaction between container color and probe position (Table 4). Repeatedmeasures analysis of variance also indicated two distinct groups of substrate temperatures among treatments in the center of the containers, although absolute differences between groups were generally smaller than at the south side (Fig. 1B). The lowest daily maximum temperatures were in flat white, gloss white, and silver containers, which averaged 3.5 to $3.8^{\circ} \mathrm{C}$ lower among treatments (Table 4).

In all containers, substrate temperature averaged $11 \%$ to $20 \%$ higher at the south side than at the center (Table 4). The greatest differences in substrate temperatures between the south side and center were in black and green containers, in which the greatest substrate temperatures were also observed among treatments (Fig. 1). Data herein indicate the greatest potential for damage to root growth and development among treatments are in the black and green containers. The critical killing temperatures of root tissues in red maple culti- vars range between 51.2 to $53.8^{\circ} \mathrm{C}$ (Sibley et al., 1999). In our study, maximum temperatures on the south side exceeded $51.2{ }^{\circ} \mathrm{C}$ on $11 \mathrm{~d}$ in black containers and $4 \mathrm{~d}$ in green containers; total hours above $51.2^{\circ} \mathrm{C}$ was $16 \mathrm{~h}$ in black containers and $8.1 \mathrm{~h}$ in green containers. Absolute maximum temperatures at the south side were $55.2{ }^{\circ} \mathrm{C}$ in black and $54.6{ }^{\circ} \mathrm{C}$ in green containers.

At the south edge of containers, root density of maples averaged 2.7 to 6.1 times greater in flat white, gloss white, and silver than in black and green containers (Table 5). The same trend was evident in the north section, although the effects were reduced compared with the warmer south edge; root density in the north section was 2.3 to 3.8 times greater in flat white, gloss white, and silver than in black and green containers. This demonstrates a significant advantage of using lighter colored containers when growing a heat-sensitive species such as maple. Root density in silver containers was also lower than in flat white containers at the south edge and lower than in gloss white containers in the north section, indicating a further advantage to root growth of maples in flat and gloss white containers than in silver containers; there was no interaction between container color and thermocouple position but for consistency, data in Table 5 are presented in the same format as Tables 1, 2, and 4.

Root density in the core and in the whole container (total) was 1.4 to 2.5 times greater in flat and gloss white containers than in all other treatments, including silver (Table 6). In silver containers, however, root density was up to 1.7 times greater than in green and black when integrated over the entire container. Thus, a general trend was observed of greatest root density in flat and gloss white containers followed by silver and finally by green and black containers. This suggests that greater heat damage occurred to roots in silver than in the flat and gloss white containers despite

Table 5. In red maples, average root densities in the north and south sections, and differences between the two locations (north-south), among treatments $(\mathrm{n}=15)$.

\begin{tabular}{|c|c|c|c|}
\hline \multirow[b]{2}{*}{ Container color } & South & North & Difference (north-south) \\
\hline & \multicolumn{3}{|c|}{ 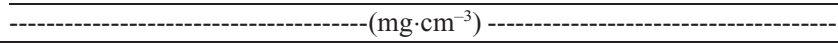 } \\
\hline Flat white & $0.853 \mathrm{~A}^{\mathrm{z}} \mathrm{a}^{\mathrm{y}}$ & $0.869 \mathrm{ABa}$ & - \\
\hline Gloss white & $0.615 \mathrm{ABb}$ & $0.957 \mathrm{Aa}$ & 0.342 \\
\hline Silver & $0.515 \mathrm{Bb}$ & $0.691 \mathrm{Ba}$ & 0.176 \\
\hline Green & $0.139 \mathrm{Ca}$ & $0.299 \mathrm{Ca}$ & - \\
\hline Black & $0.190 \mathrm{Ca}$ & $0.254 \mathrm{Ca}$ & - \\
\hline
\end{tabular}

${ }^{\mathrm{z}}$ Means followed by the same upper-case letter within a column were not significantly different $(P=0.05)$ ${ }^{y}$ Means followed by the same lower-case letter within a row were not significantly different $(P=0.05)$.

Table 6. In red maples, average root densities in the core sections and the entire container (total) and average aboveground biomass among container color treatments $(n=15)$.

\begin{tabular}{|c|c|c|c|c|c|c|c|}
\hline \multirow{4}{*}{$\begin{array}{l}\text { Container } \\
\text { color }\end{array}$} & \multirow{2}{*}{\multicolumn{2}{|c|}{ Root density }} & \multicolumn{5}{|c|}{ Aboveground biomass } \\
\hline & & & \multirow{3}{*}{$\begin{array}{c}\text { Number of } \\
\text { branches }\end{array}$} & & & & Tallest \\
\hline & Core & Total & & Stem caliper & $\begin{array}{c}\text { Total shoot } \\
\text { length }\end{array}$ & $\begin{array}{l}\text { Shoot } \\
\text { dry wt }\end{array}$ & $\begin{array}{l}\text { shoot } \\
\text { length }\end{array}$ \\
\hline & \multicolumn{2}{|c|}{$\overline{-----\left(\mathrm{mg} \cdot \mathrm{cm}^{-3}\right)^{----}}$} & & -----(mm)----- & ----(cm)---- & -- (g) -- & $--(\mathrm{cm})--$ \\
\hline Flat white & $5.10 \mathrm{~A}^{\mathrm{z}}$ & $1.92 \mathrm{~A}$ & $10.5 \mathrm{~A}$ & $4.0 \mathrm{~A}$ & $110.8 \mathrm{~A}$ & $8.4 \mathrm{~A}$ & $52.2 \mathrm{~A}$ \\
\hline Gloss white & $4.85 \mathrm{~A}$ & $1.80 \mathrm{~A}$ & $10.0 \mathrm{~A}$ & $4.1 \mathrm{~A}$ & $93.7 \mathrm{AB}$ & $7.0 \mathrm{AB}$ & $51.6 \mathrm{AB}$ \\
\hline Silver & $3.47 \mathrm{~B}$ & $1.32 \mathrm{~B}$ & $6.9 \mathrm{AB}$ & $3.1 \mathrm{~B}$ & $78.1 \mathrm{BC}$ & $5.6 \mathrm{~B}$ & $45.9 \mathrm{BC}$ \\
\hline Green & $2.47 \mathrm{~B}$ & $0.78 \mathrm{C}$ & $5.1 \mathrm{~B}$ & $2.4 \mathrm{~B}$ & $55.9 \mathrm{C}$ & $3.8 \mathrm{C}$ & $46.0 \mathrm{BC}$ \\
\hline Black & $2.43 \mathrm{~B}$ & $0.77 \mathrm{C}$ & $6.1 \mathrm{~B}$ & $2.4 \mathrm{~B}$ & $61.6 \mathrm{C}$ & $3.7 \mathrm{C}$ & $43.4 \mathrm{C}$ \\
\hline
\end{tabular}

${ }^{\mathrm{z}}$ Means followed by the same letter within a column were not significantly different $(P=0.05)$. 
higher substrate temperatures (Table 7). The largest magnitude correlations of $r=-0.43$ and -0.64 were between substrate temperature at the south side and plant growth parameters $(P=0.05)$. Substrate temperatures at the center were correlated with north, south, total root density, shoot dry weight, and total shoot length. Correlations between substrate temperature at the center and plant growth were fewer because of lower temperatures and smaller differences in temperature and plant growth among containers at the center compared with the south side.

Redbud. In the south section of containers, where presumably heat-stress effects were greatest, root density was 2.2 to 2.8 times greater in gloss white and flat white than in silver and green containers (Table 8); there was no interaction between color and position in Table 8 , but the color by position means are presented for consistency with Tables 1 to 3 . The most consistent trend in root density in the

Table 7. Pearson's correlation coefficients $(r)$ between substrate temperatures at $5 \mathrm{~cm}$, averaged over the study period, at the south side and in the center of containers. ${ }^{\mathrm{z}}$

\begin{tabular}{lllll}
\hline Plant parameter & South $r$ & $P^{\mathrm{y}}$ & Center $r$ & $P$ \\
\hline $\begin{array}{c}\text { Aboveground } \\
\text { Total shoot }\end{array}$ & -0.54 & 0.007 & -0.45 & 0.03 \\
$\quad \begin{array}{l}\text { length } \\
\text { Number of }\end{array}$ & -0.43 & 0.04 & -0.31 & 0.14 \\
$\quad$ branches & & & & \\
Caliper & -0.46 & 0.03 & -0.33 & 0.12 \\
Tallest shoot & -0.37 & 0.08 & -0.28 & 0.19 \\
Shoot dry & -0.55 & 0.006 & -0.43 & 0.04 \\
$\quad$ weight & & & & \\
& & & & \\
Root density & & & & \\
$\quad$ Core & -0.49 & 0.02 & -0.35 & 0.10 \\
$\quad$ North & -0.64 & 0.001 & -0.53 & 0.01 \\
$\quad$ South & -0.52 & 0.01 & -0.48 & 0.02 \\
$\quad$ Total & -0.56 & 0.006 & -0.44 & 0.04 \\
\hline
\end{tabular}

${ }^{\mathrm{z}}$ Data from all container colors were used in this analysis $(\mathrm{n}=25)$.

yProbability values. plant parameters in red maple and daily maximum

south, north, and core sections of the container was greater root density in flat white than in silver containers (Tables 8 and 9). For example, root density in flat white containers was $\approx 2.2$ times greater than in silver containers in the north section and 1.5 times greater than in silver containers in the core. When averaged over the entire container, total root density was 1.4 to 1.6 times greater in flat white than in silver, green, and black treatments. Thus, redbuds roots benefited most when grown in flat white containers.

Aboveground growth was highly variable and no clear patterns emerged among treatments when compared across the six measured parameters of aboveground biomass (Table 9). In fact, aboveground biomass exhibited more similarity than differences among treatments, indicating a relatively small effect of container color on plant growth. For example, there were no differences in the number of branches among treatments. In all other aboveground plant parameters, three to four of the five treatments were similar, although the patterns among treatments were inconsistent.

Redbud, which is heat-tolerant (Griffin et al., 2004), was relatively less affected by container color (and temperature) than was red maple growth but still greater in white than in black containers. Some parameters such as total root density, stem caliper, and shoot dry weight were greater in flat white than in black containers, suggesting an advantage to using flat white containers. Above- and belowground plant growth was consistently lowest among treatments in black containers, which indicates a slight disadvantage to using black containers.

In summary, our results indicated that red maple was relatively more heat-sensitive than redbud and would benefit more from production in flat or gloss white-painted containers. Growth of both species was greater in flat or gloss white-painted containers. The albedo of silver-painted containers was marginally effective in cooling root substrate and did not provide a significant improvement over black

Table 8 . In redbud, average root densities in south and north sides, and differences between the two locations (north-south), among treatments $(\mathrm{n}=11)$.

\begin{tabular}{|c|c|c|c|}
\hline \multirow[b]{2}{*}{ Container color } & South & North & Difference (north-south \\
\hline & \multicolumn{3}{|c|}{ 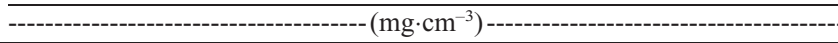 } \\
\hline Flat white & $0.290 \mathrm{AB}^{\mathrm{z}} \mathrm{a}^{\mathrm{y}}$ & $0.372 \mathrm{Aa}$ & - \\
\hline Gloss white & $0.328 \mathrm{Aa}$ & $0.267 \mathrm{ABa}$ & - \\
\hline Silver & $0.116 \mathrm{Ca}$ & $0.169 \mathrm{Ba}$ & - \\
\hline Green & $0.131 \mathrm{Cb}$ & $0.268 \mathrm{ABa}$ & 0.137 \\
\hline Black & $0.150 \mathrm{BCa}$ & $0.271 \mathrm{ABa}$ & - \\
\hline
\end{tabular}

${ }^{\mathrm{z}}$ Means followed by the same upper-case letter within a column were not significantly different $(P=0.05)$

${ }^{\mathrm{y}}$ Means followed by the same lower-case letter within a row were not significantly different $(P=0.05)$.

Table 9. In redbud, average root densities in the core sections and in the entire container (total), and average aboveground plant parameters among treatments $(n=11)$.

\begin{tabular}{|c|c|c|c|c|c|c|c|c|}
\hline \multirow{4}{*}{$\begin{array}{l}\text { Container } \\
\text { color }\end{array}$} & & & \multicolumn{6}{|c|}{ Aboveground biomass } \\
\hline & \multicolumn{2}{|c|}{ Root density } & \multirow{3}{*}{$\begin{array}{c}\text { Number } \\
\text { of branches }\end{array}$} & \multirow{3}{*}{$\begin{array}{c}\begin{array}{c}\text { Stem } \\
\text { caliper }\end{array} \\
-(\mathrm{mm})-\end{array}$} & \multirow{2}{*}{$\begin{array}{c}\text { Total } \\
\text { shoot length }\end{array}$} & \multirow{2}{*}{$\begin{array}{l}\text { Shoot } \\
\text { dry wt }\end{array}$} & \multirow{2}{*}{$\begin{array}{c}\text { Leaf } \\
\text { dry wt }\end{array}$} & \multirow{2}{*}{$\begin{array}{c}\text { Leaf } \\
\text { surface area }\end{array}$} \\
\hline & Core & Total & & & & & & \\
\hline & ----- (mg.c & $\left.\mathrm{m}^{-3}\right)----$ & & & ----- $(\mathrm{cm})$----- & --- $(g)---$ & -- (g) -- & $---\left(\mathrm{cm}^{2}\right)---$ \\
\hline Flat white & $5.67 \mathrm{~A}^{\mathrm{z}}$ & $1.67 \mathrm{~A}$ & $4.5 \mathrm{~A}$ & $5.3 \mathrm{~A}$ & $122.1 \mathrm{AB}$ & $10.8 \mathrm{~A}$ & $7.7 \mathrm{~A}$ & $640 \mathrm{AB}$ \\
\hline Gloss white & $4.97 \mathrm{AB}$ & $1.47 \mathrm{AB}$ & $6.3 \mathrm{~A}$ & $4.5 \mathrm{AB}$ & $133.2 \mathrm{AB}$ & $10.5 \mathrm{~A}$ & $7.4 \mathrm{~A}$ & $686 \mathrm{~A}$ \\
\hline Silver & $3.72 \mathrm{~B}$ & $1.04 \mathrm{~B}$ & $6.5 \mathrm{~A}$ & $4.5 \mathrm{AB}$ & $143.5 \mathrm{~A}$ & $9.1 \mathrm{AB}$ & $3.7 \mathrm{~B}$ & $372 \mathrm{~B}$ \\
\hline Green & 4.29AB & $1.22 \mathrm{~B}$ & $6.6 \mathrm{~A}$ & $3.6 \mathrm{~B}$ & $126.8 \mathrm{AB}$ & $8.1 \mathrm{~B}$ & 4.7 AB & $446 \mathrm{AB}$ \\
\hline Black & $3.99 \mathrm{~B}$ & $1.15 \mathrm{~B}$ & $4.7 \mathrm{~A}$ & $3.6 \mathrm{~B}$ & $112.0 \mathrm{~B}$ & $7.5 \mathrm{~B}$ & $6.8 \mathrm{AB}$ & $628 \mathrm{AB}$ \\
\hline
\end{tabular}

${ }^{\mathrm{z}}$ Means followed by the same letter within a column were not significantly different $(P=0.05)$. containers. Redbud growth did not respond substantially to container color, although there appeared to be a slight advantage to using flat white rather than black containers.

It is important to note in this study that temperature reduction was obtained by painting black containers white. Whitcomb (1980) evaluated an injection-molded white container and showed less temperature reduction resulting from the translucent nature of the container material. In addition to little temperature change, Whitcomb noted that light penetration into the container resulted in a thick algal growth between the plastic and the substrate. This situation is undesirable both for plant growth and future retail sales.

Development and use of an economical, durable white-colored container could be beneficial for the nursery industry. Because black containers are the industry standard and are more widely available than white-colored containers, it may be more cost-effective to focus production in white containers to heat-sensitive crops rather than heat-tolerant crops. Production of plants in white containers could reduce profit loss and reduction in plant quality caused by heat stress, especially in heatsensitive nursery crop species.

\section{Literature Cited}

Davidson, H., R. Mecklenburg, and C. Peterson. 2000. Nursery management: Administration and culture. 4th Ed. Prentice Hall, Upper Saddle River, NJ.

Dirr, M.A. 2009. Manual of woody landscape plants. 6th Ed. Stipes Publishing, Champaign, IL.

Fretz, T.A. 1971. Influence of physical conditions on summer temperatures in nursery containers. HortScience 6:400-401.

Griffin, J.J., T.G. Ranney, and D.M. Pharr. 2004. Heat and drought influence photosynthesis, water relations, and soluble carbohydrates of two ecotypes of redbud (Cercis canadensis). J. Amer. Soc. Hort. Sci. 129:497-502.

Ham, J.M., G.J. Kluitenberg, and W.J. Lamont 1993. Optical properties of plastic mulches affect the field temperature regime. J. Amer. Soc. Hort. Sci. 118:188-193.

Ingram, D.L. 1981. Characterization of temperature fluctuations and woody plant growth in white poly bags and conventional black containers. HortScience 16:762-763.

Ingram, D.L., C. Martin, and J. Ruter. 1989. Effect of heat stress on container-grown plants. Comb. Proc. Int. Plant Propagators Soc. 39:348-353.

Johnson, C.R. and D.L. Ingram. 1984. Pittosporum tobira response to container medium temperature. HortScience 19:524-525.

Martin, C.A. and D.L. Ingram. 1992. Simulation modeling of temperatures in root container media. J. Amer. Soc. Hort. Sci. 117:571-577.

Martin, C.A., D.L. Ingram, and T.A. Nell. 1989 Supraoptimal root-zone temperature alters growth and photosynthesis of holly and elm. J. Arbor. 15:272-276.

Mathers, H. 2000. Pot-in-pot container culture. Nursery Industry Assoc. of Australia. Nurs. Pap. 2:104.

Mathers, H. 2003. Summary of temperature stress issues in nursery containers and current methods of protection. HortTechnology 13:617-624.

Omae, H., A. Kumar, K. Kashiwaba, and M. Shono. 2006. Influence of high temperature on morphological characters, biomass allocation, and yield components in snap bean (Phaseolus vulgaris L.). Plant Prod. Sci. 9:200-205. 
Petkova, V., I.D. Denev, D. Cholakov, and I. Porjazov. 2007. Field screening for heat tolerant common bean cultivars (Phaseolus vulgaris L.) by measuring of chlorophyll fluorescence induction parameters. Sci. Hort. 111:101-106.

Ranney, T.G. and M.M. Peet. 1994. Heat tolerance of five species of birch (Betula): Physiological responses to supraoptimal leaf temperatures. J. Amer. Soc. Hort. Sci. 119:243-248.

Richardson-Calfee, L.E., J.R. Harris, R.H. Jones, and J.K. Fanelli. 2010. Patterns of root production and mortality during transplant establishment of landscape-sized sugar maple. J. Amer. Soc. Hort. Sci. 135:203-211.
Sibley, J.L., J.M. Ruter, and D.J. Eakes. 1999. Root membrane thermostability of red maple cultivars. J. Therm. Biol. 24:79-89.

Taiz, L. and E. Zeiger. 2002. Plant physiology. 3rd Ed. Sinauer Associates, Inc., Sunderland, MA.

Tarara, J.M. 2000. Microclimate modification with plastic mulch. HortScience 35:169-180.

Webber, J.E. and S.D. Ross. 1995. Flower induction and pollen viability for western larch. U.S. Dept. of Agriculture, For. Serv., Intermountain Research Station, Ogden, UT.

Whitcomb, C.E. 1980. Effects of containers and production bed color on root temperatures. Amer. Nurseryman 136:11, 65-67.
Whitcomb, C.E. 1999. Growing plants in a cinder block. Proc. Intl. Plant Propagators Soc. 49:527531.

Whitcomb, C.E. 2003. Plant production in containers II. Lacebark, Inc., Publications and Research, Stillwater, OK. p. 791-794.

Whitcomb, C.E. and A.C. Whitcomb. 2006. Temperature control and water conservation in aboveground containers. Proc. Int. Plant Propagators Soc. 56:588-594.

Wilkins, L.C., W.R. Graves, and A.M. Townsend. 1995. Responses to high root-zone temperature among cultivars of red maple and freeman maple. J. Environ. Hort. 13:82-85. 